\title{
乳牛の無心臓胎坚唱形の1 例
}

畣垣繁光*西田照天炏

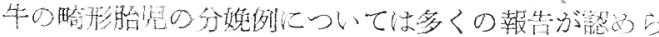

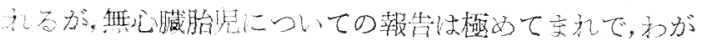

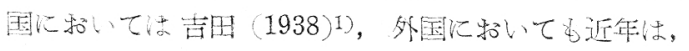
Otraway (1949)2), Wildians (1951)3), Staligeur b

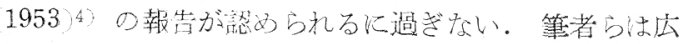

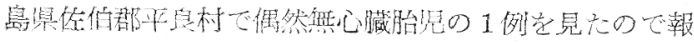

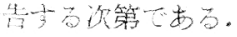

\section{観 察 経 過}

本平少小几夕々ン㮔, タキン・ロメホ・インペリアル

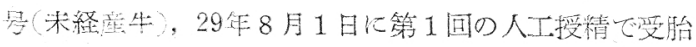

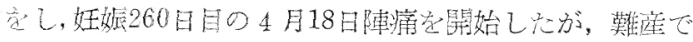

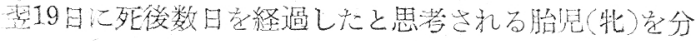

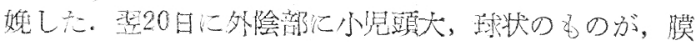

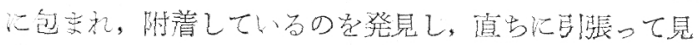

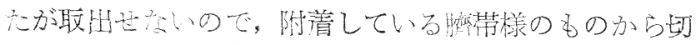

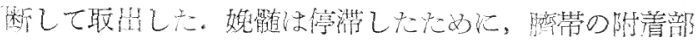
位にのいては詳細な筧察堂行うことができなかった。婏

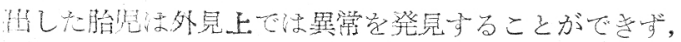

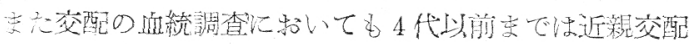

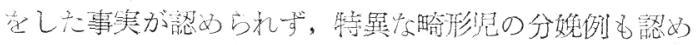

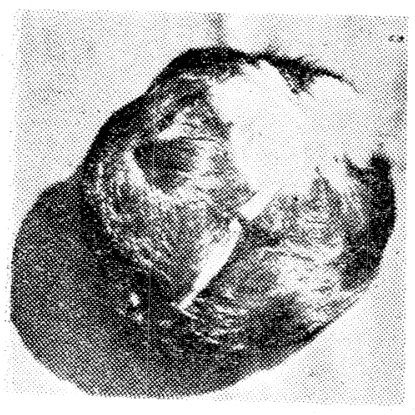

第1図然已欌胎見

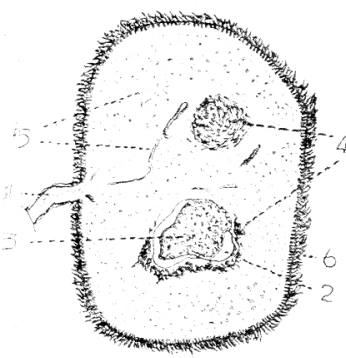

转的図同碚写図

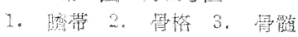

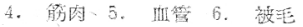

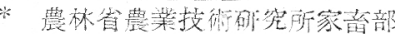

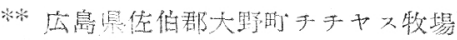

管も散兄された。

\section{考察}

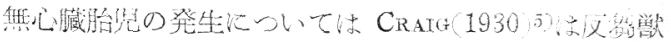

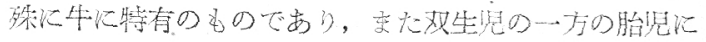

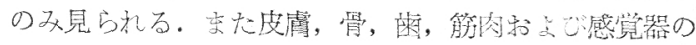

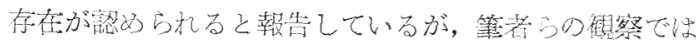

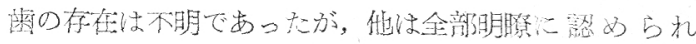

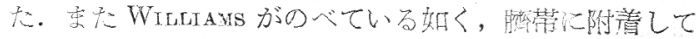
いることなどから考察して，本例は明以か汇船心瀻胎星 とい克よう。

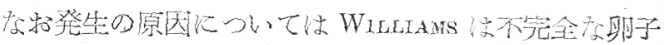

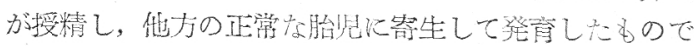

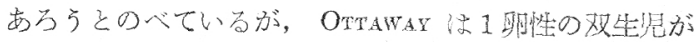
分裂して発育したが，尿膜管が接合し，次いで垬通の脂

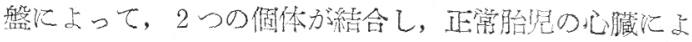

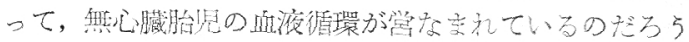
と報告している。

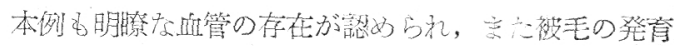
程度上り考察して, 分婏の直前究で生存し, 発消してい たるのと想像される。

\section{結語}

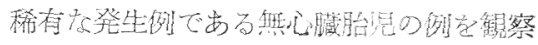
したので，1例報告をした。

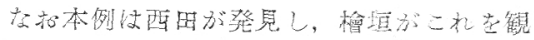
察した名のでする。

附記：本稿の印刷的に二木之同榜の畸形例

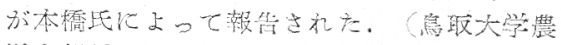
学全颙10卷，4昗，6月，1955，

\section{支献}

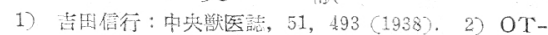
TAWAY,C.W. : British Vet. T.,105,318 (1949). 3) WILLIAMS, W.L. : Telerimary obsterios, 4th ed., 3rd Printing.(1951).4) STALICUP, 第2図同切断面
られなオンった。

この球状胎胃 (Amorphus globossus) の大妾 己は $11 \times 6 \mathrm{~cm}$ で, 重量 は $390 \mathrm{~g}$ であ，表面は 黑白斑で, 被毛す同椂に 黑と百で, 長さは勫 2.5 cmで崖った(第1図)。 こ礼を妸断して見るに， 内部水怔不正釉の管格,

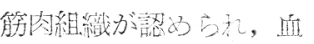

日獣会声 8 (1955) O.T. \& HERMAN, H.A.: J. Dain $S_{c i .,} 35,1299$ (1953). 5) CRAIG, J.F. : Fleming's Vetering? obsteries, 4th ed. (1930),

\section{犬゙セルペンテナ中毒}

生後16满の Springer Spaniel 種の炸犬が 1 鋔 0.25

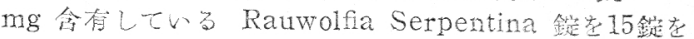

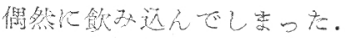

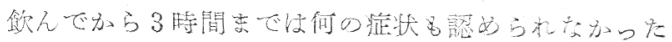

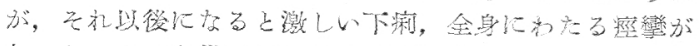

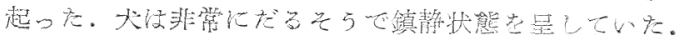

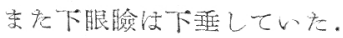

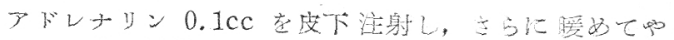

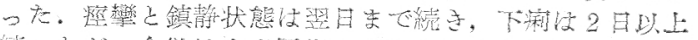

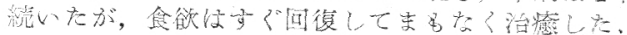

(I.H. KAifax, : A.J.V.M.A., June., 1955,472) 